\title{
The Geographical Study of "Seasonal Diseases" (II)
}

\author{
— Calendars of "Seasonal Diseases" in the World — \\ By Masako Momiyama, Sakamoto \\ Meteorological Research Institute \\ (Manuscript Received 18 February, 1961)
}

\begin{abstract}
Based upon the aralysis of the calendars of "seasonal diseases" in Japan by localities (postwar conditions compared with prewar conditions), the author assumed that "death from any disease declines in proportion to the general progress of human culture and, moreover, the season of prevalence gradually moves from summer to winter". In this paper, she has tried to test this assumption by preparing the calendars of seasonal diseases for some Western countries. As a result, it may be concluded that the author's assumption or the steady migration of diseases from summer to winter has been proved somehow or other.

It has also been proved that " the gap between diseases with high death rates and those with low rates gets wider and wider as human culture goes headway". This tendency is clearly seen in the calendar prepared for England, France and the United States: the death rate has gone off to less than 10 for such diseases as whooping cough, measles, tyhoid, dysentery, gasteritis-enteritis group, and avitaminosis, while on the other hand death frequently occurs from heart diseases, cancer, apoplexy etc.

Insofar as "the concentration of the prevalence of seasonal diseases in winter" and as "the gap between diseases with high death rates and those with low death rates are concerned, Japan cannot be regarded as ranking among the cultural countries like England or France. But in near future, it may be expected that the Japanese calendar will gradually approach the pattern of the British one.
\end{abstract}

\section{Introduction}

A geographical study of "seasonal diseases" in Japan reveals a series of interesting facts: namely, 1) Beriberi, whooping cough, gastritis-enteritis group have been prevailing in winter since the end of the Second World War though their causes were concentrated in summer before the war (1930-34), 2) even tuberculosis, which showed no seasonal rampancy before the war, has come to be prevalent in winter, 3) respiratory organ ailments, heart diseases and senility have been rife in winter as they were in the prewar period (see Fig. 1), and 4) this migration of "seasonal diseases" from summer to winter is seen not only in Tokyo Metropolis but in four other prefectures selected for this survey. ${ }^{1)}$

These findings have led the author to undertake a study of "seasonal diseases" in foreign countries on the basis of death statistics classified by disease and to make an international comparison, though on a tentative basis. But death statistics are available only for such advanced countries as England, France, Denmark, Germany and the United States. It is highly regrettable that similar statistics are unavailable for any under-developed country. Before presenting the calendars of "seasonal diseases" in these countries, it is to be noted that month-bymonth death statistics are not always itemized in accordance with the international classification of death causes common to all the countries. Thus, the method of classifying 


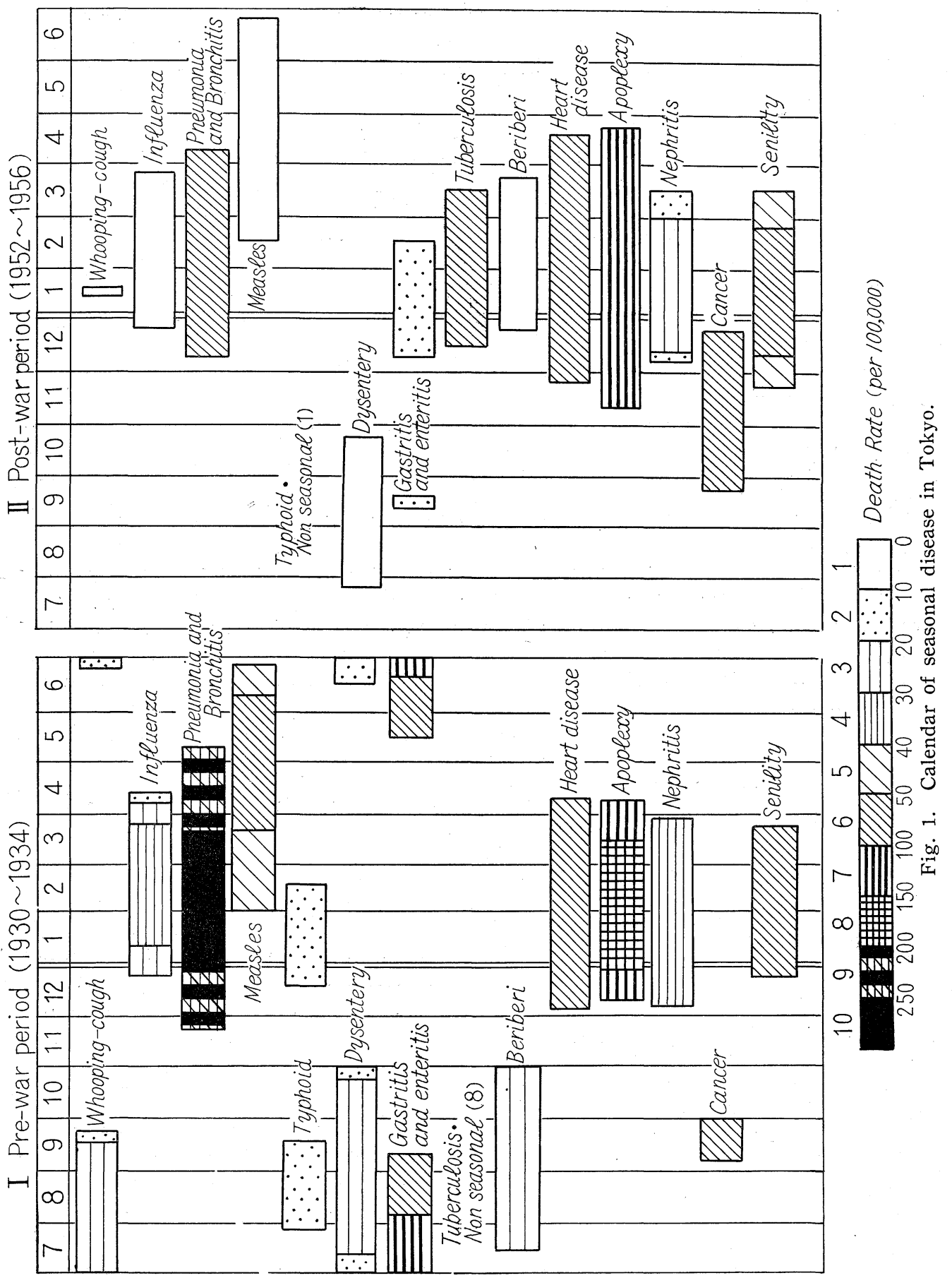


death causes in Japan cannot be applicable to an analysis of statistical data for other countries, for minor classifications widely differ among various countries. It also happens that monthly figures are classified only by large category in some foreign statistical publications, and that data are not available for some years selected for international comparison. As the result, the international study presented in this paper is not at all exhaustive but only tentative in nature.

\section{Calendars of "seasonal diseases" in world}

\section{Japan}

In postwar Japan, all diseases except dysentery and gastritis-enteritis group have been prevalent in winter as shown in Fig. 2a. Before the war, however, many maladies were rife in summer : for instance, whooping cough, typhoid, tuberculosis, beriberi and cancer, not to mention the gastritis-enteritis group. Not only that, the prewar death rate was high for pneumonia-bronchitis, gastritisenteritis, tuberculosis, etc., for which however the death rate has sharply declined since the war's termination.

\section{England*}

All the maladies appear to be prevalent in winter. In Fig. 2b, space for summer months is completely blank. No prevalence occurs in summer even for gastritis-enteritis group. It is worth mentioning that cancer begins to rage earlier than other maladies, or in October, as is the case in Japan.

Another unexpected finding is that the death rate is surprisingly high for pneumonia and bronchitis: over $100 / 100,000$ or the same rate as seen before the war in Japan. Is this not something strange in the country where Dr. Fleming discovered penicillin, as almighty remedy for pneumonia, and where the cultural standard is the highest all over the world? A similar contradiction is also witnessed for heart diseases. In winter, the death rate is over $400 / 100,000$ or five times as high as in Tokyo. Responsible factors for these phenomena will be analyzed later in this paper.

* Including England and Wales.

\section{France}

France's calendar of "seasonal diseases" is much similar to England's (see Fig. 2c). The death rates are high in winter for all the ailments. But a close look at the calendar shows some differences, namely 1) the season of prevalence starts later, or in April, for measles, and 2) the peak of the death rate curve occurs in November and December for dysentery. As for heart diseases and cancer, the death rate is as high as in England. The rate is fairly high also for pneumonia and apoplexy. In the case of senility, it is $200 \sim 300 / 100,000$, in contrasted to the low rate in England.

\section{Denmark}

For Denmark, statistical data are available for only one year or 1956 and for only nine diseases. For all this, it is evident that deaths are concentrated in winter for all these ailments (see Fig. 2d). Moreover, the death rates are very high for heart diseases and cancer and fairly high for apoplexy, as is the case in England. But the rates are appreciably low for all other illnesses: 30 or so for pneumonia-a striking difference compared with England geographically not far from England. Another feature in Denmark's calendar of "seasonal diseases" is that nephritis begins to be prevalent earlier, or in September, than in other countries.

\section{Germany**}

As for Germany, too, statistics are at hand only for one year or 1956, but the concentration of all diseases in the cold months is clearly witnessed as in England and France (see Fig. 2e). It is worthy of special mention that the season of rampancy starts one month or two later, or from mid-January through February. The summit of the death curve appears in March for all illnesses, this being ascribed to some natural and geographical conditions indigenous to Germany in all likelihood.

For heart diseases, apoplexy and cancer, the death rates are as high as in England, but much lower for pneumonia and bronchitis. The season of prevalance commences

** Including Western Germany. 

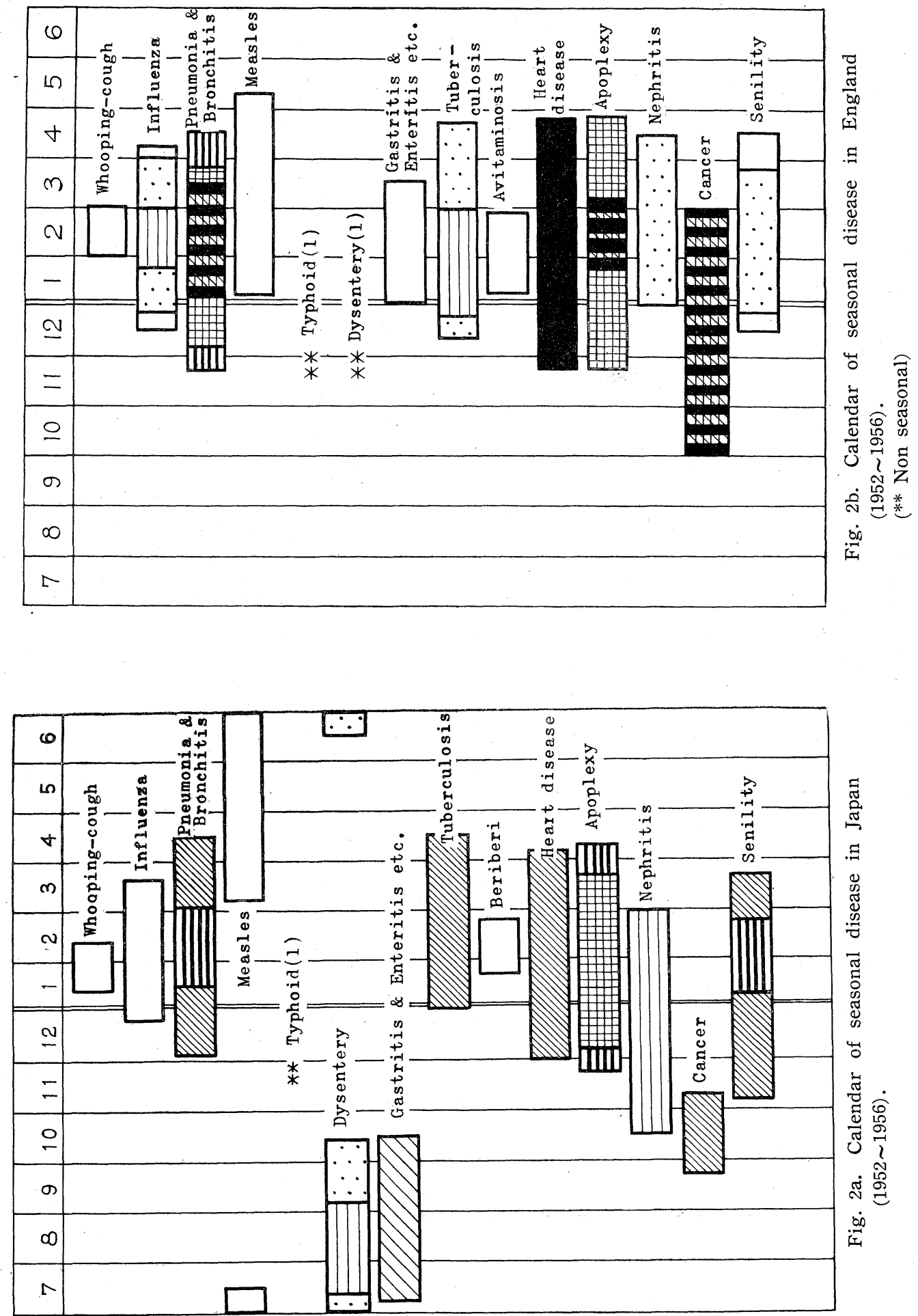

Journ. Met. Soc. Japan 

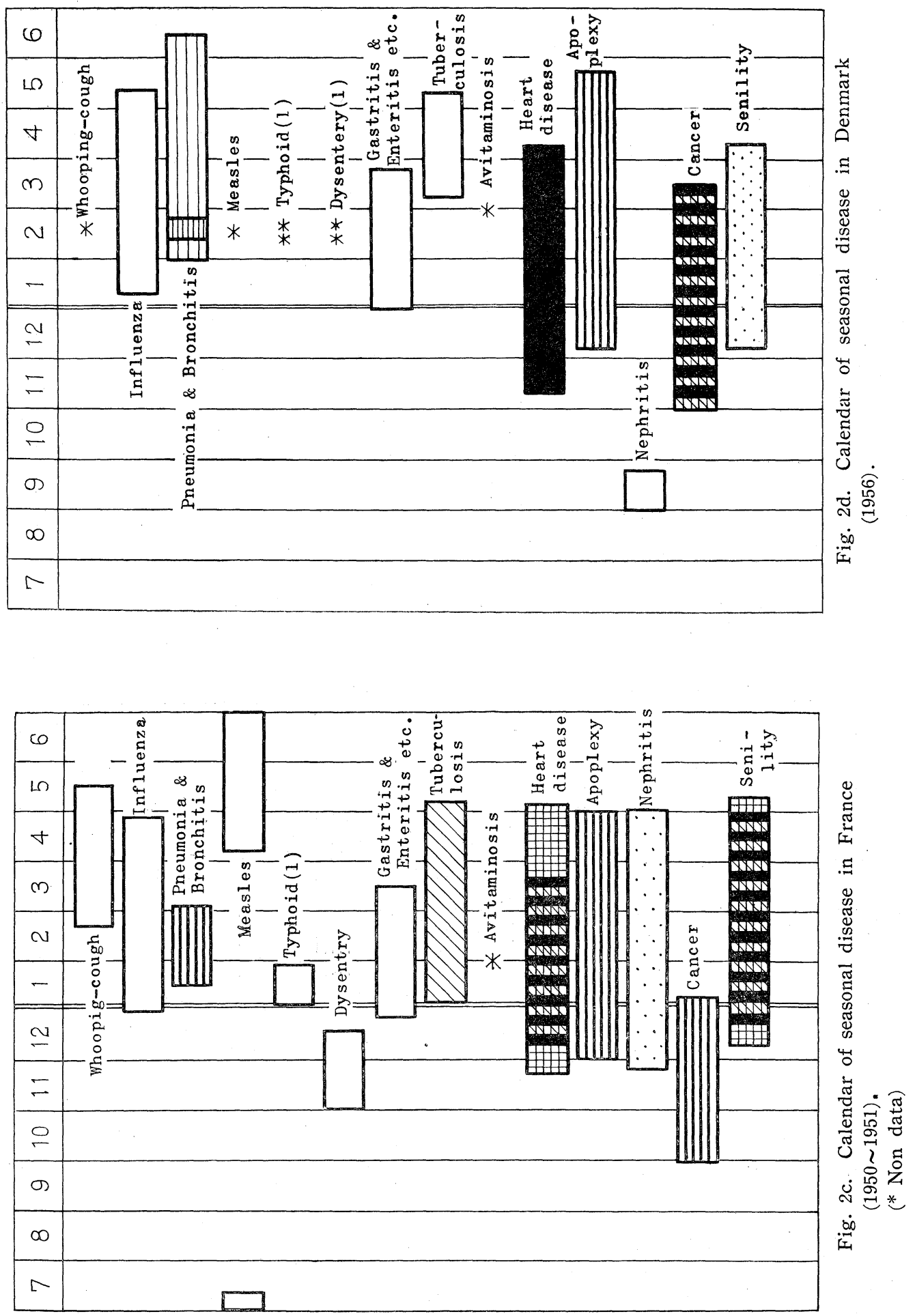

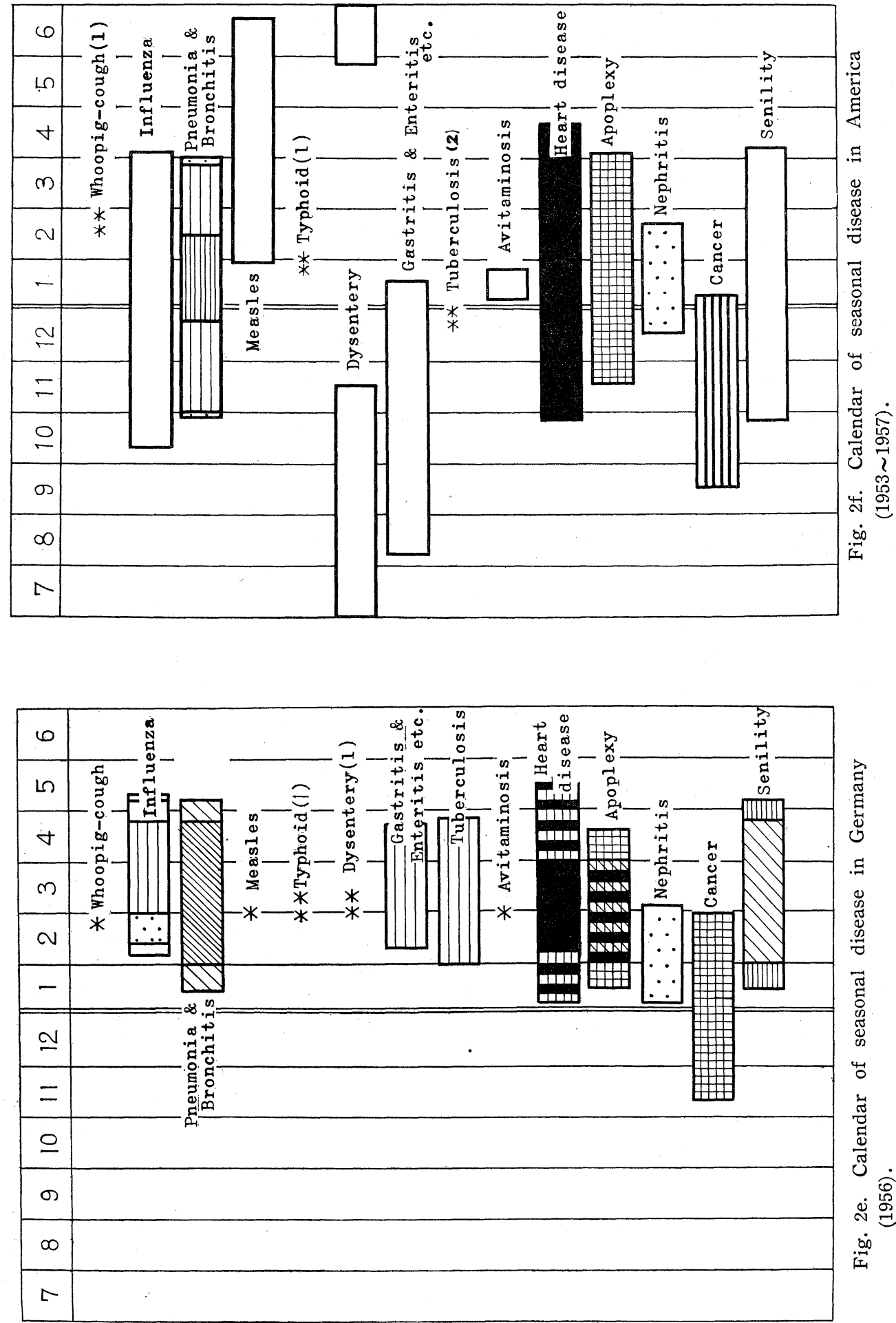
somewhat earlier, or in November, for cancer than for other ailments, but later than in England and France where cancer begins to rage in October.

\section{United States of America}

In the United States, almost all the diseases prevail much longer than in the European countries, and their concentration in the winter season is not so complete as in Europe (see Fig. 2f). In territory, the United States is 58 times as wide as England and 14 times as big as France, including deserts and under-developed provinces as well as the densely-populated cities like New York and Washington, whereas both England and France are rather compact countries geographically. Thus, it is a matter of course that "seasonal diseases" do not prevail in typical form as in the European countries.

But some regularity is seen also in the American calendar of "seasonal diseases" : namely, 1) the seasonal variations are rather moderate for all maladies, 2) the season of rampancy is far longer, or for six months, than in other countries. and 3) the death rates are high in winter for all ailments except dysentery and gastritis-enteritis group as is the case in Europe. But the winter concentration appears to have got blurred because the season of prevalence is longer. Furthermore, no seasonal raging is seen for whooping cough, typhoid, tuberculosis, etc.

The gastritis-enteritis group, which is rife in winter in Europe, prevails from August through mid-January. Avitaminosis breaks out only for a short while in January as is the case in England. Cancer begins to rage earlier, or in September, than in Europe and prevails for five months up to the first days of January. Both influenza and pneumonia shart two months earlier than in Europe, or about October, and prevail continuously up to April. In this way, the length and start of prevalence are much difierent from those in Europe for all diseases. Notwithstanding this the steady concentration of diseases in winter is self-evident.

The death rate is the highest for heart diseases or as high as in England. It is as high as in Europe also for apoplexy and cancer. But the rate is much lower for all other ailments and remains on the lowest level for one half of them: for instance, $20 \sim 30 / 100,000$ for pneumonia. Thus, it is seen that there is a very wide spread between diseases with high death rates and those with low death rates in the United States as well as in the European countries.

\section{Analysis of " seasonal diseases" in world}

Having finished the country-by-country survey of "seasonal diseases ", it is necessary for us to investigate into the geographical variations in the prevalence of "seasonal diseases" and in the death rates themselves, and then into the factors responsible for such geographical variations. This is, however, easy to speak of but difficult to accomplish. Let us first try an international comparison of some diseases in the afore-mentioned countries, which the author believes will provide us a lot of information for our geographical study of "seasonal diseases."

\section{Pneumonia and bronchitis}

One of the most interesting facts revealed in the above-quoted calendars of "seasonal diseases" is that the rate of deaths from pneumonia and bronchitis is exceedingly high in England: namely, 110/100,000 a year on the average and as high as 240 in February.

The seasonal variation curves of pneumonia-bronchitis death rates by country are shown in Fig. 3a (Germany and Denmark are omitted in this figure, for their curves are too erratic as statistical data are available for only one year). It can be seen that there is a wide spread in death rates among these selected countries, with the rate in the January-February season far exceeding 200 in England, on one hand, and, on the other, dropping to as low as 40 , or one-fifth of England's, in the United States. Both Japan and France come in the middle of the death rate range, or $100 \sim 120$ in winter. In Tokyo Metropolis alone, the variation curve is much similar to that in the United States.

Fig. 4a shows the seasonal variations of death rate indices (monthly death rates recalculated into seasonal variation indices). It is seen that the variation is the highest in England and comparatively moderate in the United States. This trend can be seen also 


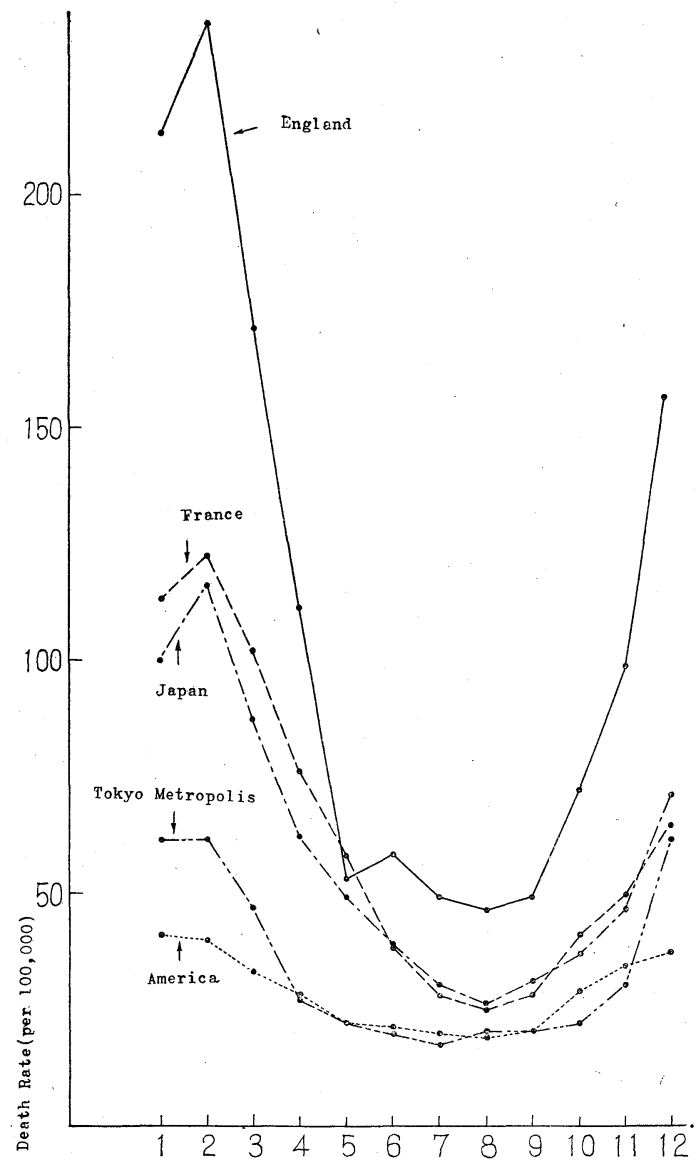

Fig. 3a. Comparison of the death rate curves of pneumonia and bronchitis in the world.

in the seasonal variation coefficient as listed in Table 1. The coefficient is as high as 0.599 for England and as low as 0.282 for the United States.

Such frequency of pneumonia and bronchitis deaths in England is ascribed, first of all, to the meteorological and climatic conditions indigenous to that country and to the contamination of air in industrial cities there.

\section{Heart diseases}

It is highly ironical that the death rate is the highest in England also for heart diseases which are not completely unrelated with pneumonia. There is no denying this tendency even if due allowance is made for the age structure of the British population. It is something surprising that deaths from heart diseases in England are 450 500 in the

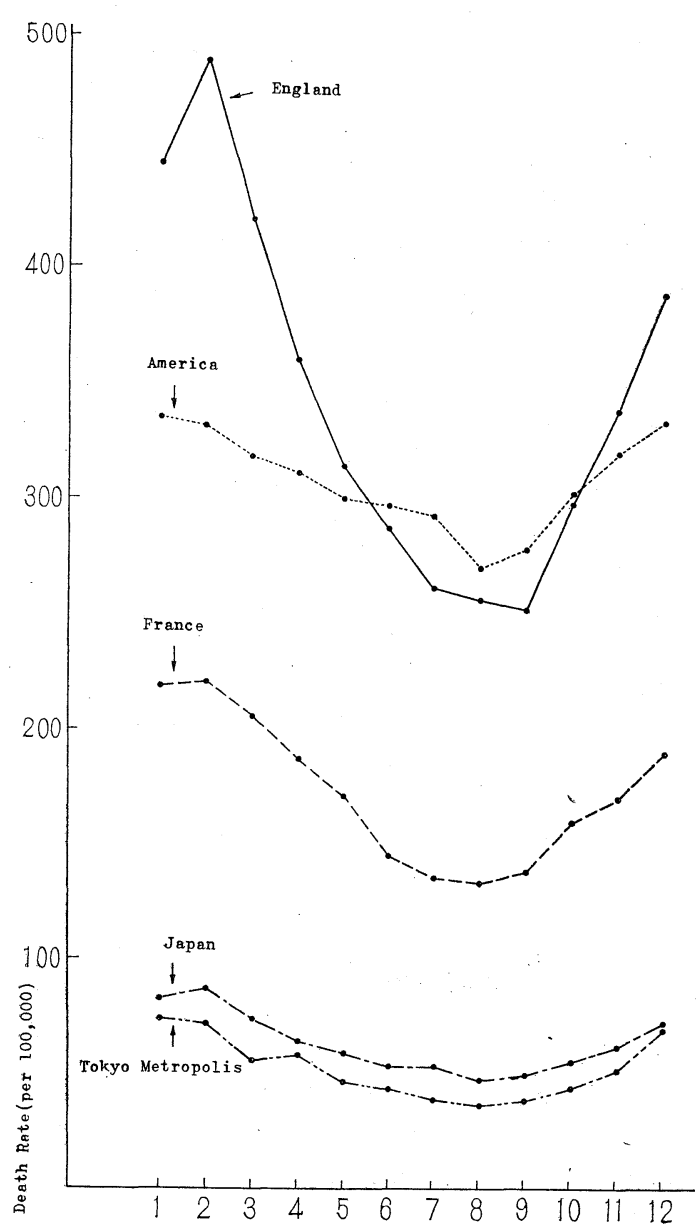

Fig. 3b. Comparison of the death rate curves of heart disease in the world.

January-February season, or twice as high as those from pneumonia.

The seasonal variation curve is again the highest for England (see Fig. 3b), and next comes the United States, followed by France and Japan. As for the United States, one interesting fact is seen: the death index curve is over 100 lower than that for England in winter but appreciably higher in summer. This clearly indicates the moderateness of the curve in the United States compared with that in England and France. The coefficient of variation is 0.068 against England's 0.222 and France's 0.177.

Exceptionally high deaths from heart diseases appear to come from the contaminated atmosphere or the most important factor responsible for the high frequency of pneu- 
Table 1. Coefficient of variation of death rates (magnitude of seasonal variations)

\begin{tabular}{l|r|r|r|r|r} 
& England & France & USA & Japan & $\begin{array}{c}\text { Tokyo } \\
\text { (Japan) }\end{array}$ \\
\hline Pneumonia \& Bronchitis & 0.599 & 0.538 & 0.282 & 0.488 & 0.505 \\
Heart Disease & 0.222 & 0.177 & 0.068 & 0.194 & 0.252 \\
Apoplexy & 0.169 & 0.149 & 0.069 & 0.148 & 0.156 \\
Cancer & 0.034 & 0.017 & 0.031 & 0.047 & 0.070 \\
\hline
\end{tabular}

monia deaths in England. It is imaginable that the air contamination causes the disorder of the respiratory organs, which in turn brings about a heavier burden upon the heart. Another factor may well be found in the fact that the Westerners take much animal fat in daily diet. If too much fatty food is taken, superfluous fat accumulates around the heart, so its function gets weak, particularly in the cold season. Then, some people say that the so-called social stress is the third factor for the frequency of heart diseases in advanced countries.

The latter two factors, or fatty food and social stress, can be seen alsó in France, Germany and the United States, if the air contamination is not the case with them. Little wonder that heart diseases register the highest death rate in the United States, and the second highest rate, next only to that of senility, in France.

In Japan, on the other hand, the death rate is much lower for heart diseases than that in the Western countries, only one-tenth that in England in the season of prevalence. This may be regarded as having relations with the daily diet of Japanese people lacking in animal fat. It may be expected, however, that deaths from heart diseases certainly will increase in future along with the modernization of Japanese diet. The death rates from heart diseases in the coming years are estimated as shown in Table 2: they will gradually approach the level now

Table 2. Death rate estimates for heart diseases (Japan)

\begin{tabular}{c|r|r}
\hline & \multicolumn{1}{|c|}{ Male } & \multicolumn{1}{|c}{ Female } \\
\hline 1954 & 61.6 & 58.8 \\
1970 & 79.9 & 74.1 \\
1990 & 106.3 & 103.4 \\
2010 & 160.8 & 144.9 \\
\hline
\end{tabular}

prevailing in the Western countries, but it is half a century hence that the death rate will reach 160 , or still lower than that in the Western countries.

\section{Apoplexy}

The death rate is the highest in England for apoplexy as well as for pneumonia and heart diseases, climbing up to 215 in February or at the peak of prevalence. Next comes Germany, followed by Japan, France and the United States in the order named. The seasonal variation coefficient is the smallest, or 0.069 , in the United States just as in the case of heart diseases and pneumonia. This again clearly indicates that the seasonal variation is much less conspicuous in the United States than in all other countries.

But no plausible explanation can yet be found as for the differences in apoplexy death

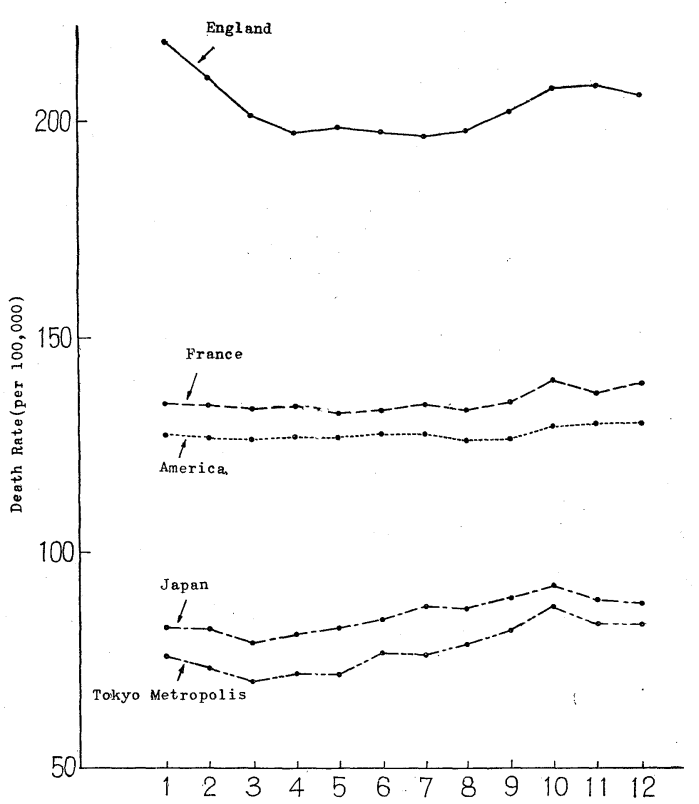

Fig. 3c. Comparison of the death rate curves of cancer in the world. 
rates among various countries in the world and various districts in one country (Japan in the author's analysis).

\section{Cancer}

In the case of cancer, the death rate is again the highest in England, but the seasonal variation curve is much less sharp in all the countries than for pneumonia, heart diseases and apoplexy (Fig. 3c). It may well be said, however, that deaths from this malady are frequent (100 or so) all the year round in every country.

In England, the peak appears in January (instead of October or November in other countries) and rises to as high as 220 , but the spread from the bottom (seen in April) is not more than 20 . The death rate stands at 100 150 in France and the United States and at a lower level, or $50 \sim 100$, in Japan, where the peak comes at less than 100 in October,

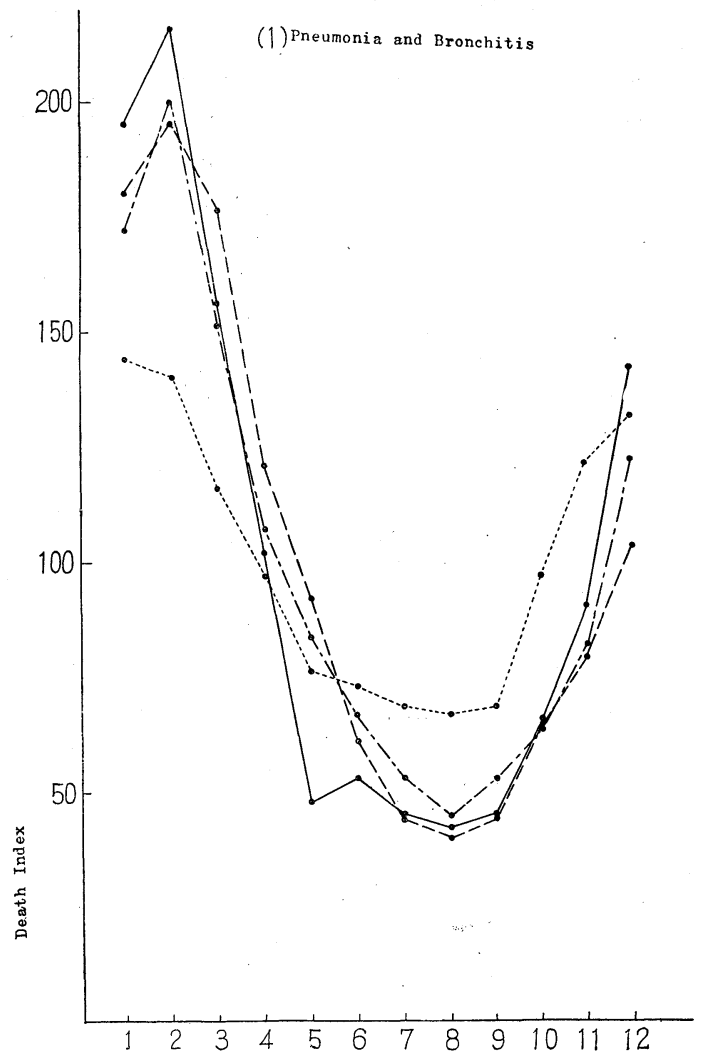

England _- France ---, America ......, Japan - - -

Fig. 4a. Comparison of the death index curves pneumonia and bronchitis in the world.
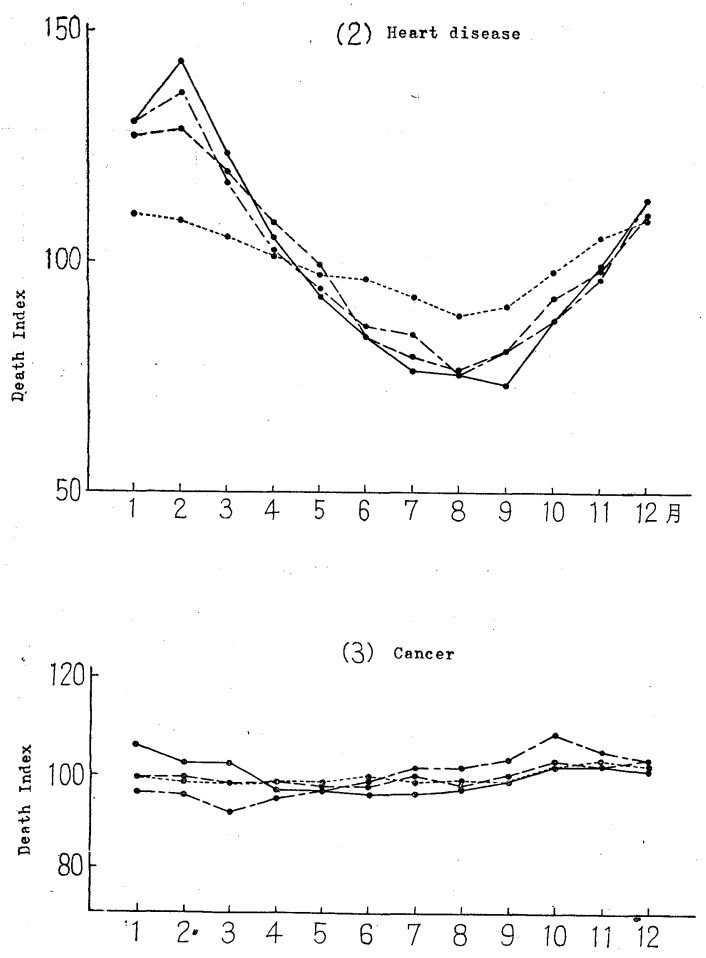

England - - France ---, America $\cdots \cdot \cdot$, Japan -- -

Fig. 4b. Same as Fig. 4a but for heart disease (2) and cancer (3).

or less than one half of the British summit.

As for cancer, the seasonal variation is much less marked in all the countries as may be noted in Fig. 4c. The coefficient of variation is only 0.034 even in England and much smaller than that for other maladies, or 0.031 in the United States and 0.017 in France.

Not only in Japan but in the Western countries as well, the season of prevalence appears late in autumn (October and November) and not in winter (see Fig. 5), whereas almost all other diseases now are concentrated in winter. Why is this disease still prevalent in fall? Is it, however, going to move to winter in the wake of other ailments? The author can yet find no exact answer to these and other questions.

In England, for instance, the exceptionally high death rate probably comes from the fact that many people die from lung cancer in particular. It must be noted that the lung cancer is often caused by too much smoking. And there can be no doubt that its high 

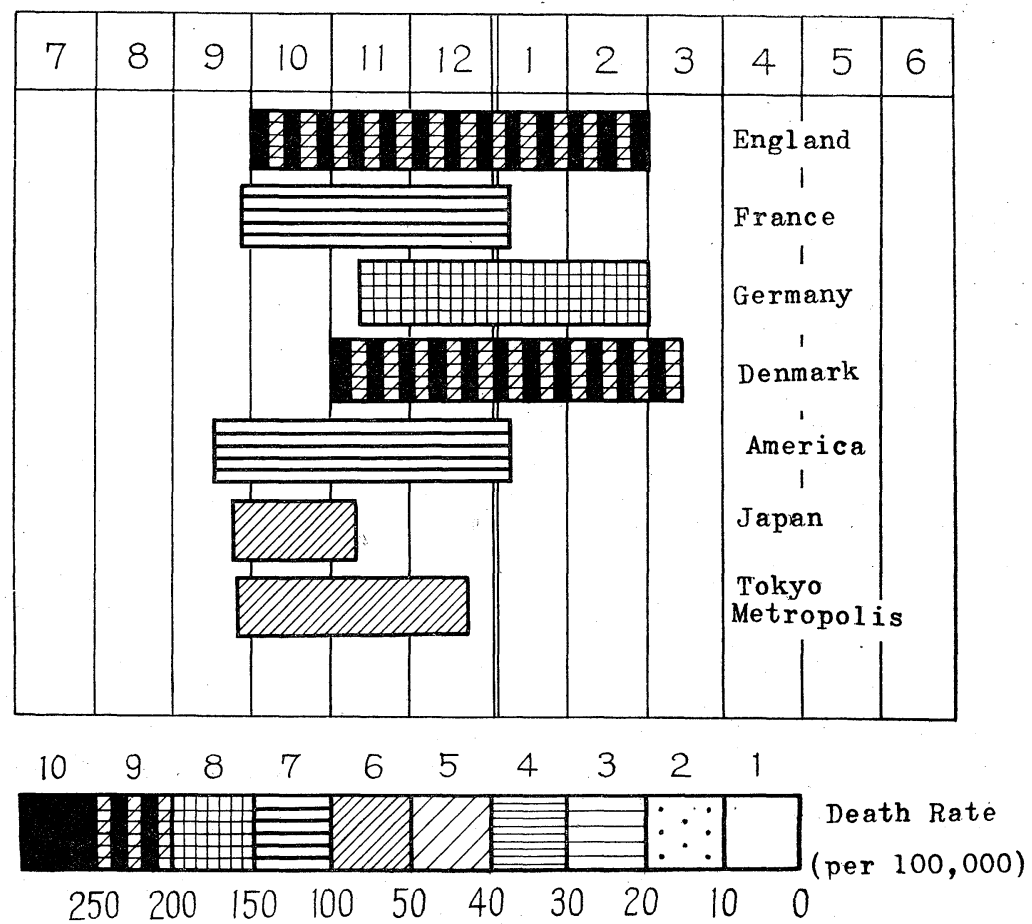

Fig. 5. Calendar of cancer in the world.

rampancy in England has some relation or other with the afore-mentioned air contamination, and that the seasonal variation of cancer deaths is closely connected with the seasonal variation of air contamination. It must be emphasized, however, that discussions must be conducted by differentiating the conditions for cancer breakout from the process of cancer growth.

\section{3. "Seasonal diseases" and cultural pro- gress}

Based upon her analysis of the calendars of "seasonal diseases" in Japan (postwar conditions compared with prewar conditions in various prefectures), the author assumed that deaths from any disease decline in proportion to the general progress of human culture and, moreover, the season of prevalence gradually moves from summer to winter. $^{2)}$ In this paper, she has tried to test this assumption by preparing the calendars of "seasonal diseases" for some Western countries for which comparable statistical data are available. From the foregoing, it may be concluded that the latter half of the author's assumption, or the steady migration of diseases from hot to cold months has been proved somehow or other. But this is not the case with the first half of her assumption, or the gradual shrinkage of the death rate.

As for old age ailments, the death rate may not be expected to decline along with the cultural development, but it really is a surprise for the author to have found the death rate "rising up contrary to" the cultural progress for some other diseases. We had better assume that " the gap between diseases with high death rates and those with low rates gets wider and wider as human culture goes headway."

This tendency is clearly witnessed in the calendars prepared for England, France and the United States: the death rate has gone off to less than 10 for such ailments as whooping cough, measles, typhoid, dysentery, gastritis-enteritis group, and avitaminosis, so much so indeed that no season of prevalence can be seen in some cases, while on the other hand deaths frequently occur (the rate ranging from 150 to over 250) from heart diseases, cancer, apoplexy and senility (the last named particulaly in France). The gap 
between these two groups of illnesses is surprisingly wide.

There are some exceptions. One example is pneumonia and bronchitis in England: namely, the death rate stands at upwards of 200 in spite of the cultural headway and the discovery of penicillin, and this is attributed to the special climate and the air contamination above referred to. It may be concluded that in such advanced countries as England, the conditions created by man along with the cultural progress are liable to boost the death rates for some diseases.

The same may be said of heart diseases and cancer, for which the death rates are exceedingly high in all the Western countries. Cultural life, though it contributes to the decrease from some ailments, often results in the increase of deaths for others popularly called "cultural diseases".

It the winter concentration of diseases and the wider gap between deaths from various illnesses, England appears to be the most conspicuous, followed by France. No apparent regularity is seen for the United States wide in territory and various in climate.

The exceptionally high death rate for senility in France, contrasted to the low rates in England and the United States, is another phenomenon worthy of special mention. In England and the United States, authorities concerned are apparently so particular about death causes that they often carry out an exhaustive review into the reported senility cases, and this is no doubt one of the factors responsible for the statistically low deaths from senility.

Insofar as "the concentration of the prevalence of seasonal diseases in winter" is concerned, Japan cannot be regarded as ranking among the cultural countries like Britain or France. First of all, dysentery, gastritis-enteritis etc. still prevails in summer, or their prevalence has not yet moved to the cold months. Then, the gap between diseases with high death rates and those with low death rates has not got so wide as in the Western countries: the death rate has slipped so low as in the Western countries for whooping cough, influenza, measles, avitaminosis etc. but is relatively high $(40 \sim 100)$ for digestive organ diseases and tuberculosis, while on the other hand the death rate is much lower $(50 \sim 100)$ than in the Western countries for such cultural maladies as cancer and heart diseases. It is more adequate to say that all the diseases but senility have been arrested to an appreciable degree in the Western countries, and that the death rate thus remains relatively high only for old age diseases. In Japan, many people die from various diseases (left unarrested) except senility before they reach the old age. In other words, deaths are distributed rather evenly among a number of diseases in Japan in striking contrast to the lopsided concentration of deaths among old age illnesses in the Western countries.

Let us have another look at the calendars of the "seasonal diseases" (Fig. 2a-f). In the British calendar, there are three or four dark-shaded bars contrasted to the light bars. In the Japanese calendar, the light and shade differences are much blurred. In the German calendar, the contrast is much less sharp than in that of England and France, but the tendency of winter concentration is clearly seen.

As for Japan, the contemporary calendar shows some signs of progress or culturalization, compared with its counterparts in 1910's and 1920's, but it falls far behind the British and French calendars in many respects. The historical progress of the Japanese calendar is not at all unrelated with its backwardness in international comparison: historically and geographically reflected herein is the development of human society.

From the foregoing, it may be expected that the Japanese calendar will gradually approach the pattern of the British one. About the future death rates of heart diseases and apoplexy in Japan, some estimates are made and published, but they will change, depending upon the modernization of Japanese diet. In light and shade contrast, the Japanese calendar years hence will become similar to that of England except the relatively low death rate for pneumonia. By that time, however, effective steps will have been taken for preventation of the evil effects of the air contamination in England, 
and in such a case there will be little difference between the two calendars. The death rate will shrink for heart diseases and cancer as remedial measures will be elaborated, and deaths will be concentrated step by step upon senility.

Written in memory of Dr. Fumio Tada's 61st Birthday.

\section{References}

1) Momiyama, M. (1960): The geographical study of "Seasonal Diseases" (I ). Tentative calendars of "Seasonal Diseases" in Japan. J. Met. Soc. Japan, 38, 47-60.

2) Momiyama, M. (1960): Calendars of seasonal diseases in the world. Shizen, 15, 32-41.

\section{季節病の医学地理学的研究 (II)}

——世界の季節病カレンダー—

粐山政子

(気象研究所)

日本諸地域の季節病カレンダーの地理的, 歴史的な此較から得られた“一般に文化が進めば進むほど, いるいる な死亡の流行期が冬飞移動していくのではないか”という私の推論を，外国であ成立つかどうかを検討するため欧米 諸国のカレンダーを作つた。その結果イギリス，フランス，デンマーク，ドイッではすべての季節病が極立つた冬季 集中を示し，夏季は空白状態であることがわかつた。アメリカは欧洲ほどには見事ではないが（地域が広大で，地理 的条件があまりとも变化富むためか)，やはり冬季集中の傾向は認められる。

つぎに“文化が発達してくると，死亡率の高い病気と低い病気の開きがますます大きくなる”という事実も明ら かになつた。欧米では心臓病, 癌, 蔵出血などの老人病は死亡率が高いが, 一方, 下痢・腸炎, 腸チフス, 赤痢, 百 日咳，麻疹などが極めて低く，両者の開きは極めて大きい。これと反して日本では死亡率の高い病気と低い病気との 差は，それ程大きくはない。つまり日本の死亡率はかなり多くの種類の病気飞比較的平均した形で死亡がばらまかれ ているのに反して，欧米のそれは老人病に集中して極立つたコントラストを示している。

イギリスに肺炎・気管支炎が著しく高いのは特有な気象条件と，それ煤煙がとすなつた大気污染の影響による あのといわれる。また欧来諸国一般に心臟病が高いのは, 脂肪食の大量摂取, 社会的ストレス等の影響とされる。こ れらは癌をす含めて，交明国家特有の条件で，かえつて死亡率が高まつている皮肉な例ともいうこと染できる。

日本ああろ少し文明化されると，イギリス等のカレンダーの姿近づくということは容易淮測されよう。 本論交は東京大学教授多田交男先生の還暦記念論交であることを付記します。 